\title{
PENINGKATAN KEMAMPUAN MENULIS PANTUN MELALUI PENDEKATAN PEMBELAJARAN CONTEXTUAL TEACHING AND LEARNING (CTL) SISWA KELAS IV SEKOLAH DASAR NEGERI 24 AIR SALEH Oleh \\ Wartik \\ SD Negeri 24 Air Saleh \\ Wartiknugroho2887@gmail.com
}

\begin{abstract}
The purpose of this research is to improve the writing skill of fourth grade students of SD 24 Air Saleh. This study was conducted in two cycles. The data obtained from the observation of teacher and student activities while learning, while to measure the success of writing ability pantun evaluation test in each cycle. In the first cycle the average value of the students 'activity is $57.90 \%$, in the second cycle, it reaches $85.23 \%$, meaning that the students' activity is increased by $27.33 \%$. Furthermore, the value of students' ability in writing pantun in the first cycle reached 62.33, after the action taken on the second cycle reached 76.83. So there is an increase of 14.4. Based on these values, it can be concluded that the Contextual Teaching and Learning (CTL) learning approach can improve the writing ability of fourth grade pupil of 24 Air Saleh State High School.
\end{abstract}

Keywords: Contextual Teaching and Learning

\section{PENDAHULUAN}

Selama ini pengajaran apresiasi sastra berlangsung monoton, sangat membosankan dan tidak menarik. Guru tidak mengajak siswa untuk menikmati indahnya karya sastra, tapi diberi hafalan tentang nama-nama pengarang dan karya-karyanya (Baksin, 2008:98). Sering ditemui di sekolah-sekolah bahwa, tidak semua guru bahasa Indonesia mampu mengajarkan apresiasi sastra dengan baik. Guru yang mahir mengajarkan bahasa Indonesia belum tentu mampu tampil memikat saat mengajar sastra.Kebanyakan guru menganggap siswa telah mengerti teknik menulis pantun, karena pantun sering dijumpai di acara-acara TV. Namun kenyataannya hasil pembelajaran menulis pantun sangat rendah. Siswa tidak mampu menggali ide-ide kreatif untuk menemukan kata-kata yang tepat dalam membuat sampiran maupun isi pantun.

Berdasarkan kegiatan ulangan harian tentang materi menulis pantun kelas IV di Sekolah Dasar Negeri 24 Air Saleh, ditemukan bahwa kemampuan siswa menulis pantun tingkat ketuntasannya masih rendah. Nilai ratarata yang diperoleh siswa untuk materi menulis pada semester pertama tahun pelajaran 2016/2017 hanya 53,67, 
sedangkan Kriteria Ketuntasan Minimal (KKM) yang harus dipenuhi sebesar 70 . Oleh sebab itu, untuk mengatasi permasalahan di atas diperlukan upaya untuk memperbaiki proses pembelajaran. Salah satu usaha yang dapat dilakukan guru adalah dengan menerapkan suatu pendekatan yang tepat. Peneliti memilih pendekatan pembelajaran Contextual Teaching and Learning (CTL).Pertimbangan peneliti memilih pendekatan tersebut adalah keefektifannya dalam materi menulis pantun, karenapendekatan pembelajaran ini dilakukan dengan cara mengajak siswa melihat situasi di lingkungan belajarnya untuk merangsang daya pikirsiswa menemukan ide-ide kreatif. Penelitian ini menggunakan penelitian tindakan kelas (PTK) dengan judul "Peningkatan Kemampuan Menulis Pantun Melalui Pendekatan Pembelajaran Contextual Teaching and Learning (CTL) Siswa Kelas IV Sekolah Dasar Negeri 24 Air Saleh". Berdasarkan hal di atas, maka masalah yang teridentifikasi adalah sebagai berikut. Apakah yang menyebabkan rendahnya kemampuan menulis pantun siswakelas IV Sekolah Dasar Negeri 24 Air Saleh?, dan Bagaimanakah meningkatkan kemampuan menulis pantun tersebut, serta apakah pendekatan pembelajaran Contextual Teaching and
Learning

(CTL)

dapat

meningkatkankemampuan menulis pantun siswakelas IV di Sekolah Dasar Negeri 24 Air Saleh?

\section{Perumusan Masalah}

Rumusan masalah dalam penelitian ini adalah "Bagaimanakah meningkatkan kemampuan menulis pantunsiswa kelas IV Sekolah Dasar Negeri 24 Air Saleh melalui pendekatan pembelajaran Contextual Teaching and Learning(CTL)? Pemecahan dari masalah ini adalah memperbaiki proses pembelajaran melalui pendekatan pembelajaran Contextual Teaching and Learning (CTL). Adapun tujuan pembelajaran menulis pantun dengan pendekatan pembelajaran Contextual Teaching and Learning (CTL) dalam penelitian ini adalah siswa mampu menulis pantun anak yang menarik dengan tema "sekolahku" sesuai dengan ciri-ciri pantun. Sedangkan tujuan penelitian ini untuk meningkatkan kemampuan menulis pantun siswa kelas IV Sekolah Dasar Negeri 24 Air Saleh melalui pendekatan pembelajaran Contextual Teaching and Learning (CTL).Hasil penelitian tindakan kelas ini diharapkan dapat memberikan manfaat sebagai berikut. (1). Bagi guru, diharapkan dapat memperoleh pengetahuan yang nyata mengenai pendekatan pembelajaran Contextual 
Teaching and Learning (CTL)(2) Bagi siswa, diharapkan siswa lebih aktif dan kreaktifdalam proses pembelajaran sehingga dapat meningkatkan hasil kemampuan menulis pantun. (3) Bagi sekolah, diharapkan dapat meningkatkan mutu pembelajaranmenulis pantun dengan penerapan pendekatan pembelajaran Contextual Teaching and Learning (CTL)

\section{KAJIAN PUSTAKA}

\section{A. Teori yang Melandasi PTK}

Menulis adalah suatu keterampilan berbahasa yang dipergunakan untuk berkomunikasi secara tidak langsung. Dalam kegiatan menulis, penulis haruslah terampil memanfaatkan grafolegi, struktur bahasa, dan kosa kata (Tarigan, 2008:3-4).Agar bisa menulis dengan baik dituntut adanya kemampuan menulis, adapun kemampuan menulis adalah kekuatan atau kesanggupan untuk mengkomunisasikan pikiran, perasaan dan kemauan, sehingga dapat dimengerti oleh pembaca.Suatu tulisan dapat menyenangkan untuk dibaca apabila ditata sedemikian rupa, sehingga akan merupakan rangkaian kata dan kalimat yang baik secara kohesif maupun koheren.Seseorang yang mampu menulis berarti ia mampu menyusun gagasan yang baik (Wardarita, 2014:1415). Seorang penulis mempunyai kekuatan karena bahasa tulisnya. Orang yang rajin menulis akan semakin meningkat kemahiran bahasanya. Ada beberapa nilai idial yang didapatkan dari menulis, antara lain: nilai kecerdasan, nilai kependidikan, nilai kejiwaan, nilai kemasyarakatan, nilai kefilsafatan, dan nilai popularitas (WA, 2009:7). Seseorang yang menulis pasti punya tujuan.Tujuan umum menulis adalah sebagai alat komunikasi secara tidak langsung.Pada prinsipnya menulis adalah menyampaikan pokok pikiran penulis kepada pembaca, sehingga pembaca memahami maksud yang disampaikan melalui tulisan tersebut (Kusumaningsih, 2013:67). Ada beberapa syarat yang bisa dibangun untuk menciptakan mood menulis, yaitu pilihlah suasana yang menyenangkan,menulis tema yang sesuai dengan minat kita masingmasing, jika di tengah menulis mengalami kesulitan, maka lebih baik berhenti dahulu, kita bisa mengendapkan apa yang sudah kita tulis, baru mencari celah yang baik untuk melanjutkan tulisan kita (Junaedi, 2015:42)Dari pendapat para ahli di atas dapat disimpulkan bahwa menulis adalah suatu kegiatan penyampaian pesan (komunikasi) dengan menggunakan bahasa tulis sebagai alat atau medianya. Sedangkan pesan adalah isi atau muatan 
yang terkandung dalam suatu tulisan.Tulisan merupakan sebuah simbol atau lambang bahasa yang dapat dilihat dan disepakati pemakainya.Pantun merupakan puisi tertua asli milik orang Indonesia, khususnya orang melayu.Pada mulanya pantun hanya dinyanyikan atau disenandungkan (A.S, 2010:217).

Berbagai pantun berkembang menurut kebudayaan dan adat istiadat daerah masing-masing. Orang jawa menyebut pantun dengan nama parikan atau wangsalan. Orang Sunda menyebut pantun dengan nama sindiran. Di Madura pantun di sebut paparegan. Lain halnya dengan di Tapanuli, di daerah ini pantun disebut ende-ende (Muryanto, 2009:7--11). Pantun berbentuk quatrin yang terdiri atas baris-baris pendek dan mempunyai irama ujung tetap yang berfungsi sebagai ungkapan pikiran dan perasaan secara ringkas dan padat (Muryanto,2009:3).Walaupun pantun merupakan bentuk puisi lama namun pantun masih sangat populer hingga saat ini, karena pantun merupakan tulisan yang pendek dan syarat makna (Widya, 2009:54). Pantun tidak mengandung unsur-unsur magis,karena pantun dilahirkan dari unsur sukma yang merefleksikan perasaan dan pikiran dalam mengolah kehidupan (Rampan, 2014: vi--vii).Selain itu melalui orang- orang tua disekitar kehidupan kita pantun disebarkan secara lisan, sehingga pantun dapat populer (Rosdiana, 2009:77) Pola pantun ditandai dengan bentuk berbait yang berisi empat larik. Setiap lariknya menggunakan empat kata dengan rima akhirnya a-ba-b.Empat kata itu umumnya terdiri dari delapan hingga dua belas suku kata.Di jaman sekarang, pantun sering digunakan terutama dalam acara hiburan.Berdasarkan uraian di atas, dapat disimpulkan bahwa pantun mempunyai struktur dan kaidah sebagai berikut, terdiri atas empat baris, tiap baris terdiri atas 8 sampai 12 suku kata, dua baris pertama disebut sampiran dan dua baris berikutnya disebut isi, pantun mementingkan rima akhir dengan pola a-b-a-b. Bunyi akhir baris pertama sama dengan bunyi akhir baris ketiga, dan bunyi akhir pada baris kedua sama dengan bunyi akhir baris keempat.

Setiap orang memiliki ketertarikan yang berbeda dalam membuat pantun.Semua itu tergantung tema yang mereka suka(Darisman, 2015:91).Agar bisa menulis pantun dengan baik, kita terlebih dahulu harus memahami struktur atau kaidah pantun. Setelah itu kita menentukan tema serta pernyataan-pernyataan yang akan dipantunkan (Kosasih, 2016:145).Pantun menggunakan kata denotasi. Kata-kata 
denotasi tersebut dirangkaikan dengan baik sehingga membentuk sebuah kalimat yang mempunyai arti kias(Widya, 2008:43).Setelah memahami kaidah dan syarat pantun kita baru dapat menulispantun.Muryanto (2009:61--63) menjelaskan bahwa agar dapat menulis pantun dengan baikdiperlukan langkah-langkah sebagai berikut antara lain: menentukan tema, membuat isi pantun, membuat sampiran, setelah isi dan sampirannya pantun selesai dibuat, langkah terakhir yaitu menggabungkannya. Sebagaimana penjelasan di atas, bahwa untuk memperbaiki pembelajaran peneliti menggunakan pendekatan pembelajaran Contextual Teaching and Learning (CTL). Komalasari $(2014,54)$ menjelaskan bahwa pendekatan pembelajaran adalah titik tolak atausudut pandang kita terhadap proses pembelajaran, yang merujuk pada pandangan tentang terjadinya suatu proses yang sifatnya masih sangat umum. Pokok pikiran Komalasari itu sejalan dengan pendapat Wardarita.

(2014:35), yang mengatakan bahwa pendekatan merupakan titik tolak atau sudut pandang di mana kita memandang seluruh masalah yang ada dalam program belajar mengajar.Johnson (2009:14) menjelaskan bahwa pendekatan Contextual Teaching and
Learning (CTL) adalah sebuah sitem belajar yang didasarkan pada filosofi bahwa siswa mampu menyerap pelajaran apabila mereka menangkap makna materi akademis, mengerti makna tugas sekolah dan mengaitkan dengankehidupan sehari-hari yaitu dengan konteks lingkungan pribadinya, sosialnya dan budayanya.Pendekatan pembelajaran Contextual Teaching and Learning (CTL) memungkinkan proses belajar yang tenang dan menyenangkan, karena pembelajaran dilakukan secara alamiah, sehingga peserta didik dapat mempratikkan langsung apa-apa yang dipelajarinya (Mulyasa, 2009:217--218). Pendekatan pembelajaran inijuga membantu guru mengaitkan materi yang diajarkannya dengan situasi dunia nyata. Pendekatan ini melibatkan tujuh komponen utama pembelajaran efektif yaitu: konstruksitivisme (Constructivism), bertanya (Questioning), menemukan (inquiri), komunitas belajar (Leanrning community), pemodelan (Modelling), dan penilaian sebenarnya (Authehentic Assessment) (Akib, 2015:4). Menurut Trianto (2012:107), pendekatan pembelajaran Contextual Teaching and Learning (CTL) mengasumsikan bahwa pemikiran mencari makna dapat terjadi ketika siswa dihadapkan dengan situasi nyata, karena apa yang dihadapi itu 
masuk akal dan dapat dicerna oleh pemikiran mereka.Berdasarkan pendapat para ahli di atas dapat disimpulkan bahwa, pendekatan pembelajaran Contextual Teaching and Learning (CTL) adalah suatu pendekatan pembelajaran yang membawa siswa belajar ke dunia nyata. Pendekatan pembelajaran ini membuat siswa aktif, kreaktif dan inovatif.Dalam hal ini guru sebagai pasilitator harus membuat suasana nyaman sehingga siswa mampu belajar dengan baik.

Teori yang melandasi pendekatan Contextual Teaching and Learning (CTL). Kelima teori itu adalah sebagai berikut. (a) Knowledge-Based Contructivisme,

(b)Efforet-Based Learning/ Incremental Theory of Intellegence. (c) Socialization, (d) Situated Learning,(e) Distributet Learning,Akib (2015:13--14)

Komalasari (2014:19--22) menjelaskan ada 4 teori belajar yang mendukung pendekatan pembelajaran Contextual Teaching and Learning (CTL) diantaranya sebagai berikut. (a) Teori Perkembangan dari Piaget, (b) Teori Free DiscoveryLearning dari Bruner,(c) Teori Meaningful Learning dari Ausubel,(d) Teori Belajar Vygotsky. Menurut (Johnson, 2014:15) terdapat delapan karakteristik pendekatan Contextual Teacher and Learaning
(CTL), diantaranya sebagai berikut.(a) Melakukan hubungan yang bermakna (making meaningful connections), (b) Melakukan kegiatan-kegiatan yang signifikan (doing significanwork)(c)Belajar yang diatur sendiri (self regulatet learning), (d) Bekerja sama (collaborating), (e) Berpikir kritis dan kreaktif (critical and creative thinking).f. Mengasuh atau memelihara pribadi siswa (nurturing theindividual), (g) Mencapai standar yang tinggi (reaching High Standart), (h) Menggunakanpenilaian autentik (using authentic assesment)

Adapun ciri-ciri pendekatan contextual teaching and learning(CTL). Adanya kerjasama antar semua pihak, menekankan pentingnya pemecahan masalah,bermuara pada keragaman konteks kehidupan siswayang berbedabeda, saling menunjang, tidak membosankan, belajar dengan bergairah, pembelajaran terintegrasi. menggunakan berbagai sumber. siswa aktif, sharing dengan teman, siswa kritis, guru kreaktif, dinding kelas penuh dengan hasil karya siswa, petapeta,gambar,artikel dan sebagainya, laporan kepada orang tua bukan hanya rapor,tetapi hasil karya siswa, (Mulyasa (2016:219))

Akib(2015:15) mengatakan bahwa untuk menyesuaikan kebutuhanindividual 
siswa, maka guru harus melakukan halhal sebagai berikut:

(a).Merencanakan pembelajaran sesuai dengan perkembangan mental siswa (devellopmentally appropriate). (b). Membentuk group belajar yang saling bergantung (interdependent Leanrning groups). (c). Mempertimbangkan keragaman siswa (dipersity of students). (d). Menyediakan lingkungan yang mendukung pembelajaran mandir(self-regulated learning) dengan 3karakteristik umumnya (keragaman berpikir,penggunaan strategi dan motivasi berkelanjutan). (e). Memperhatikan multi intelgensi (multiple intelgences). (f).Menggunakan teknik bertanya (questioning) yang meningkatkan belajar siswa, perkembangan pemecahan masalah dan ketrampilan berpikir tingkat tinggi.(g). Mengembangkan pemikiran bahwa siswa belajar lebih bermakna jika diberi kesempatan bekerja, menemukan dan menguntruksi sendiri pengetahuan dan ketrampilan baru (contruktivism) (h)Memfasilitasi kegiatan penemuan(inquiry)siswa memperolehpengetahuanya sendiri(bukan hasil mengingat sejumlah fakta). (i). Mengembangkan sikap ingin tahu siswa melalui pengajuan pertanyaan(quistions).(j)Menciptakan komunitas belajar (learning comunity) dengan membangun kerjasama antar siswa.(k). Memodelkan (modelling) sesuatu agar siswa dapat meniru untukmemperoleh pengetahuan dan kerampilan baru. (1). Mengarahkan siswa untuk merefleksikan tentang dipelajari. (m). Menerapkan penilaian autentik (authentic assessment). (n). Guru seharusnya merancang pengajaran dengan mengaitkan konsep yang dipelajari dengan mempertimbangkan pengalaman siswa dengan lingkungan kehidupannya. (o). Mendorong siswa untuk mengaitkan pembelajarannya dengan pengetahuansebelumnya dan fenomena sehari-hari serta menyimpulkannyaberdasarkan konsep dan teori.

Akib (2015:6) pendekatan pembelajaran Contextual Teaching and Learningdapat diterapkan kurikulum apa saja, dan bidang studi apa saja, dan kelas yang bagaimanapun keadaannya. Secara garis besar langkah-langkahnya(a) Kembangkan pemikiran bahwa anak akan belajar lebih bermakna dengan cara bekerjasendiri, dan mengkontruksi sendiri pengetahuan serta pengalamannya yang baru.(b). Laksanakan sejauh mungkin kegiatan inquiri untuk semua topik.(c) Kembangkan sikap ingin tahu dengan bertanya.(d). Ciptakan masyarakat 
belajar. (e). Hadirkan model sebagai contoh pembelajaran. (f). Lakukan refleksi di akhir pertemuan.(g). Lakukan penilaian yang sebenarnya dengan berbagai cara.

Menurut (Trianto, 2009:107) langkahlangkah pendekatan pembelajaran Contextual Teaching and Learning (CTL) adalah: (a)Guru membagi siswa dalam beberapa kelompok secara acak dengan menciptakan masyarakat belajar. (b)Siswa mengamati media yang diberikan guru untuk menemukan pengetahuan baru dan menambah pengalamannya. (c) Perwakilan kelompok membacakanhasil diskusi, dan kelompok lain mengomentari.(d)Guru memberikan tes secara individual mencakup semua materi yang telah dipelajari.

Menurut Mahanani (2014) beberapa keunggulan dan kelemahan pendekatan pembelajaran Contextual Teaching and Learning (CTL).

Keunggulan Pendekatan Contextual Teaching and Learning (CTL)adalah (1) Pembelajaran lebih produktif dan mampu menumbuhkan penguatan konsep siswa.(2) Menekankan pada aktifitas siswa secara penuh. Kelas dalam pembelajaran Contexstualadalah sebagai tempat untuk menguji data hasil temuan mereka.(3) Materi pelajaran ditemukan sendiri oleh siswa, bukan hasil pemberian dari guru.(4) Penerapan pembelajaran Contekstual Teaching and
Learning (CTL), dapat menciptakan suasana pembelajaran yang bermakna.

Adapun Kelemahan Pendekatan

Contextual Teaching and Learning (CTL)adalah

(1) Diperlukan waktu pembelajaran yang cukup lama. (2) Jika guru tidak dapat mengendalikan kelas, dapat menciptakan kelas yang kurang kondusif. (3) Guru lebih intensif membimbing karena dalam pendekatan pembelajaran Contextual Teaching and Learning (CTL) guru tidak lagi sebagai pusat informasi. Tugas guru adalah mengelola kelas. Guru memberikan kesempatan kepada siswa untuk menemukan atau menerapkan sendiri, ide-ide dan strategi-strategi mereka sendiri untuk belajar

B. Penelitian Terdahulu yang Relevan
yang relevan dengan pernah dilakukan oleh Mistari Mahasiswa Fakultas Keguruan dan Ilmu Pendidikan Universitas Sebelas Maret Surakarta.Judul penelitian "PeningkatanKetrampilan Menulis Pantun melalui Model Pembelajaran Contextual Teaching and Learning Bagi siswa kelas IV SDN 1 Gombang Tahun Ajaran 2010/2011'.Hasil penelitianya, nilai rata-rata pada test awal 59,13. Kemudian pada siklusI mencapai 61,42 , dan pada siklus II mencapai 74,97. 
Siswa tuntas sebelum tindakan hanya 4 siswa $(26.67 \%)$, pada siklus 1 naik menjadi 7 siswa (46.67\%). Pada siklus II mencapai 12 siswa (80 \%). Nilai tertinggi pada awal test 74 , siklus I naik menjadi 77 dan siklus II meningkat menjadi 92. (Mistari, 2011:63).

\section{Kerangka Pikir}

Berdasarkan permasalahan yang teridentifikasi ,peneliti berupaya memperbaiki pembelajaran untuk meningkatkan kemampuan menulis pantun pada siswa kelas IV melalui pendekatan Contextual Teaching and Learning (CTL). Alasan peneliti memilih pendekatan tersebutkarena pendekatan tersebut sangat efektif untuk diterapkan dalam pembelajaran menulis pantun, sebab siswa dalam pendekatan ini disuruh melihat dan mengamati benda-benda atau kejadian di sekitar mereka belajar. Dari pengamatan tersebut siswa akan lebih kreatif menggali ide-ide serta imajinasinya.

Kriteria KetuntasanMinimal (KKM) yang telah ditetapkan di SDN 24 Air Saleh adalah 70.Apabila hasil penelitian tindakan kelas ini dapat meningkatkan hasil kemampuan menulis pantun, maka pendekatan Contextual Teaching and Learning (CTL) dapat dijadikan salah satu referensi bagi pendidik lainnya dalam pembelajaran menulis pantun pada siswa kelas IV sekolah
dasar.Berdasarkan pemikiran diatas, hipotesis tindakan penelitian yang dapat disimpulkan bahwapendekatan pembelajaran Contextual Teaching and Learning (CTL) dapat meningkatkan kemampuan menulis pantun siswa kelas IV Sekolah Dasar Negeri 24 Air Saleh.

Kriteria keberhasilan penelitian tindakan kelas ini diukur dari peningkatan hasil kemampuan menulis pantun siswa kelas IV Sekolah Dasar Negeri 24 Air Saleh. Jika kemampuan siswa menulis pantuntelah mencapai nilai (KKM) yakni 70, maka siswa tersebut dinyatakan tuntas. Tingkat keberhasilan PTK dinyatakan berhasil apabila 85\% siswa telah mencapai KKM (70).

\section{RENCANA DAN PROSEDUR PENELITIAN}

Subjek Penelitian adalah siswa kelas IV Sekolah Dasar Negeri 24 Air Saleh yang berjumlah 30 orang.Penelitian tindakan kelas ini menggunakan siklus. Hasil dari siklus I dipergunakan untuk melaksanakan tindakan siklus berikutnya. Penelitian ini dilakukan pada bulan Juni tahun pelajaran 2016/2017. Penelitian dilaksanakan di kelas IV Sekolah Dasar Negeri 24 Air Saleh Kabupaten Banyuasin. Penelitian inimenggunakan model penelitian tindakan kelas yang dikemukakan oleh Kemmis dan Mc Taggart yang menggunakan empat langkah 
pengulangan yang dinamakan siklus. Setiap siklus terdiridari perencanaan, pelaksanaan tindakan, pengamatan (observasi) dan perefleksian.Setiap siklus pelaksanaan pembelajaran dilakukan 2 kali pertemuan, dan setiap pertemuan terdiri dari $2 \times 35$ menit. Pengumpulan data pada penelitian ini adalah menggunakan tenik tes dan teknik non tes. Sedangkan alat untuk pengumpul data adalah instrument tes. Teknik analisis Data pada penelitian ini adalah disimpulkan secara deskriptif kualitatif.

\section{IV.HASIL DAN PEMBAHASAN}

\section{A. HASIL PENELITIAN}

Berdasarkan analisis dari tes awal, diketahui nilai dari 30 siswa yang mencapai KKM hanya 9 siswa atau $30 \%$. Nilai rata-rata siswa hanya 53,67 , pada hal KKM yang harus di capai adalah 70 dan minimal harus dicapai oleh 26 siswa yang tuntas $85 \%$.Berdasarkan analisis data pada siklus I yaitu analisis hasil tes kemampuan menulis pantun dapat dilihat bahwa siswa yang berhasil mencapai KKM hanya 14 atau 46,67\% sedangkan nilai rata-rata kelasnya mencapai 62,33. Berdasarkan hal tersebut, maka siklus I dinyatakan belum berhasil. Setelah diadakan tindakan pada siklus II nilai siswa meningkat.Jika pada siklus I nilai rata-rata siswa 62,33 , siklus II meningkat 76,83 . Jadi mengalami peningkatan sejumlah 14,5. Siswa yang berhasil mencapai nilai KKM pada siklus I sejumlah 14 siswa atau (46,67\%) pada siklus II meningkat 27 siswa atau $(90,00 \%)$. Jadi ada peningkatan sejumlah (43.33\%). Berdasarkan analisis data nilai kemampuan menulis pantun tersebut maka dapat dikatakan bahwa pembelajaran menulis pantunmelalui pendekatan pembelajaran Contextual Teaching and Learning(CTL) KKM yang ditentukan,yakni 70 dan siswa yang mencapai KKM sejumlah 85\% atau 26 siswa. Pada akhir pembelajaran siklus II ini telah mencapai $(90 \%)$ atau 27 siswa.

\section{B. PEMBAHASAN}

Hasil siklus Imenunjukkan bahwa nilai presentase keaktifan siswa masih rendah,yaitu hanya15siswa yang berhasil (50\%), sedangkan siswa berkategori cukup mencapai 8 siswa $(26,67 \%)$, dan siswa yang berkategori kurang sejumlah 7 siswa (23,33\%).Hasil observasi yang dilakukan oleh teman sejawat terhadap guru selamapembelajaran, guruberkategori baik. Artinya guru mempunyai kompetensi dalam mengajar dan mengelola kelas. Berdasarkan hasil pengolahan data, nilai rata-rata tes 
kemampuan menulis pantun siswa pada tindakan siklus I hanya 14 siswa yang nilainya mencapai $\mathrm{KKM}(46,67 \%)$ dari 30 siswa. Sedangkan nilai rata-rata perkelas mencapai 62,33 Artinya dalam menulis pantun kemampuan siswa masih rendah, karena 16 siswa masih di bawah KKM.

Berdasarkan pengamatan dari lima aspek,semuanya mengalami peningkatan dari siklus sebelumnya.siklus I nilai rata-rata keaktifan siswa $56,99 \%$ pada siklus II mencapai $\quad 85,23 \%$,mengalami peningkatan 28,24\%. Teman sejawat mengasumsikan bahwa penyebab rendahnya kemampuan siswa dalam menulis pantun bukan disebabkan oleh ketidakmampuan guru dalam mengajar dan mengelola kelas. Dalam dua kali pembelajaran nilai kemampuan guru sangat bagus.Berdasarkananalisis hasil tes kemampuan siswa dalam menulis pantun pada tindakan ke II mengalami peningkatan yang baik. Jika pada siklus I nilai rata-rata siswa 62,33 maka pada siklus II ini mengalami peningkatan menjadi 76,83 Jadi mengalami peningkatan sejumlah 14,5 . Siswa yang berhasil mencapai nilai KKM pada siklus I sejumlah 14 siswa atau $(46,67 \%)$ pada siklus II mengalami peningkatan sejumlah 27 siswa atau (90,00\%). Berdasarkan hasil analisis tersebut maka ada peningkatan sejumlah (43.33\%).

1. Rekapitulasi Nilai ObservasiAgar pembacapaham tentang hasilyang diperoleh dari observasikeaktifan siswa di bawah ini disajikan tabel rekapitulasi keaktifan siswa.

REKAPITULASI NILAI RATA-RATA PER SIKLUS KEAKTIFAN MENULIS PANTUN SISWA KELAS IV SDN 24 AIR SALEH

\begin{tabular}{|c|c|c|c|c|}
\hline \multicolumn{5}{|c|}{ Aspek Pengamatan } \\
\hline Ber pendapat & Mena nggapi & $\begin{array}{c}\text { Mengerja kan } \\
\text { Tugas }\end{array}$ & $\begin{array}{c}\text { Memotivasi } \\
\text { Tugas-Tugas }\end{array}$ & $\begin{array}{c}\text { Mau } \\
\text { Menerima } \\
\text { Pendapat }\end{array}$ \\
\hline \multicolumn{5}{|c|}{ Tindakan Siklus I } \\
\hline $52,50 \%$ & $56,66 \%$ & $60,83 \%$ & $60,33 \%$ & $59,16 \%$ \\
\hline \multicolumn{5}{|c|}{ Tindakan Siklus II } \\
\hline $85,00 \%$ & $82,50 \%$ & $85,00 \%$ & $88,33 \%$ & $85,23 \%$ \\
\hline
\end{tabular}

PRESENTASE PENINGKATAN NILAI OBSERVASIKEAKTIFAN MENULIS 
PANTUN SISWA KELAS IVSDN 24 AIR SALEH

\begin{tabular}{|l|l|l|l|}
\hline No & Tindakan Persiklus & $\begin{array}{l}\text { Presentase } \\
\text { Peningkatan }\end{array}$ & Peningkatan \\
\hline 1 & Tindakan siklus I & $\mathbf{5 0 \%}$ & - \\
\hline 2 & Tindakan siklus II & $\mathbf{9 0 \%}$ & $\mathbf{4 0 \%}$ \\
\hline
\end{tabular}

\section{Rekapitulasi Nilai Rata-rata dan Presentase Kemampuan Menulis} Pantun Persiklus Tindakan

\section{Presentase Nilai Rata-rata}

\begin{tabular}{|l|l|l|l|l|}
\hline $\begin{array}{l}\text { Pelaksanaan } \\
\text { Tindakan }\end{array}$ & $\begin{array}{l}\text { Kesesuaian } \\
\text { Syarat } \\
\text { Pantun }\end{array}$ & $\begin{array}{l}\text { Ketepatan } \\
\text { Memilih Kata }\end{array}$ & $\begin{array}{l}\text { Kesesuaian } \\
\text { dengan Tema }\end{array}$ & Jumlah \\
\hline $\begin{array}{l}\text { Tindakan } \\
\text { Siklus I }\end{array}$ & 21,33 & 21,33 & 20,33 & 62,33 \\
\hline $\begin{array}{l}\text { Tindakan } \\
\text { Siklus II }\end{array}$ & 26,16 & 25,33 & 25,16 & 76,83 \\
\hline
\end{tabular}

Presentase Peningkatan Nilai Tes Kemampuan Menulis Pantun Siswa Kelas IV SDN 24 Air Saleh

\begin{tabular}{|l|l|l|l|}
\hline No & Tindakan Persiklus & $\begin{array}{l}\text { Presentase } \\
\text { Peningkatan }\end{array}$ & Peningkatan \\
\hline 1 & Tindakan siklus I & $62,33 \%$ & - \\
\hline 2 & Tindakan siklus II & $76,83 \%$ & $14,50 \%$ \\
\hline
\end{tabular}

\section{SIMPULAN}

Penelitian tindakan kelas dengan judul PeningkatanKemampuan Menulis Pantun Melalui Pendekatan Pembelajaran Contextual Teaching and Learning (CTL) Siswa Kelas IV SDN 24 Air Saleh, dilakukan sebanyak dua siklus. Hasil penelitian setiap siklus

dianalisis dan dideskripsikan kemudian nilai-nilai tersebut diolah dengan menggunakan rumus yang ditentukan sebelumnya. Berdasarkan hasil analisis, diketahui bahwa nilai keaktifan siswa dalam proses pembelajaran menulis pantun pada siklus I baru mencapai $56,99 \%$. Setelah diadakan perbaikan pada siklus II menjadi $85,23 \%$. Hal ini menunjukkan peningkatan sebesar $29,24 \%$.Selanjutnya nilai menulis pantun pada siklus I dapat dideskripsikan bahwa nilai rata-rata siswa baru mencapai 62,33, setelah diadakan tindakan siklus II 
mencapaimencapai 76,83 . Jadi terjadi peningkatan nilai rata-rata kemampuan siswa menulis pantun mencapai 14,50 . Berdasarkan analisis data tersebut diketahui bahwa siswa yang mencapai KKM pada siklus I baru 14 siswa (46,67\%) dan pada siklus II meningkat menjadi 27 siswa (90\%). Hal ini terjadi peningkatan sebesar $(43,33 \%)$.Berdasarkan uraian di atas maka dapat disimpulkan bahwa kemampuan menulis pantun siswa pada penelitian ini telah mencapai KKM yaitu 70 dan minimal (85\%) siswa telah mencapai target KKM. Dari 30 siswa dalam penelitian ini hanya 3 siswa atau (10\%) yang belum mencapai KKM. Berdasarkan analisis data, maka dapat dinyatakan bahwa penelitian tindakan kelas tentang Peningkatan Kemampuan Menulis Pantun Melalui Pendekatan Pembelajaran Contextual Teaching and Learning (CTL) dapat meningkatkan kemampuan siswa dalam pembelajaran menulis pantun.

\section{DAFTAR PUSTAKA}

A.S, Nadjua. 2010. Inti Sari Kata Bahasa Indonesia. Surabaya: Triana Media

Aqib, Zainal. 2015. Model-model, Media dan Strategi Pembelajaran Kontekstual

(Inovatif). Bandung: Yrama Widya.

Baksin, Askurifai. 2008. Aplikasi Praktis Pengajaran Sastra. Bandung: PT Pribumi Mekar
Darisman, Muh.2015. Trip Mudah Belajar Bahasa Indonesia 4. Jakarta: Yudistira

Johnson,Elaine.B. 2014. CTL Contextual Teaching \& Learning. Bandung: Kaifa.

Junaedi, fajar. 2015. Menulis Kreaktif. Jakarta: Prenadamedia Group.

Kosasih, 2016.Jenis-Jenis Teks. Analisis Fungsi Struktur dan Kaidah Serta Langkahnya dalam Mata Pelajaran Bahasa Indonesia, $S M A, M A, S M K$. Bandung: Yrama Widya.

Mahanani, Fauzan A, 2014. http://www.m-edukasi.web.id diunduh tanggal 04 Mei 2017.

Mistari.2011.Peningkatan Kemampuan Menulis Pantun dengan Menggunakan Model Kontekstual bagi siswa kelas IV SDN Gombang.eprints.uns.ac.id 03.1502 April 2016.

Mulyasa. 2009. Kurikulum yang disempurnakan (Pengembangan Standar Kompetensdan Kompetensi Dasar). Bandung: PT Remaja Rosdakarya

Redakdi Balai Pustaka. 2011. Pantun Melayu. Jakarta: PT Balai Pustaka.

Rampan, Korrie Layun. 2014. Mantra Syair dan Pantun di Tengah Kehidupan Masyakat Modern. Bandung: Yrama Widya. 
Rosdiana,Yusi dkk. 2009. Bahasa dan Sastra Indonesia di SD. Bandung: Universitas Terbuka.

Tarigan. 2008 Menulis Sebagai Suatu KeterampilanBerbahasa Bandung:Angkasa.

Trianto. 2012. Mendesain Model Pembelajaran InovatifProgresif.Jakarta:Kencana Prenada Media Group.

W A, Monica abigail. 2009. Surabaya: JP Books.

Widya, Wendi. 2009. Bedah Puisi Lama. Klaten: PT Intan Pariwara. 